Meta

Journal des traducteurs

Translators' Journal

\title{
Translation from Arabic into Hebrew in Israel - An Overview
}

\section{Hannah Amit-Kochavi}

Volume 43, numéro 1, mars 1998

La traduction et l'interprétation en Israël

Translation and Interpreting in Israel

URI : https://id.erudit.org/iderudit/001883ar

DOI : https://doi.org/10.7202/001883ar

Aller au sommaire du numéro

Éditeur(s)

Les Presses de l'Université de Montréal

ISSN

0026-0452 (imprimé)

1492-1421 (numérique)

Découvrir la revue

Citer cet article

Amit-Kochavi, H. (1998). Translation from Arabic into Hebrew in Israel - An Overview. Meta, 43(1), 79-86. https://doi.org/10.7202/001883ar

\section{Résumé de l'article}

Cet article décrit l'état actuel de la traduction littéraire et non littéraire, de l'arabe vers l'hébreu, dans le contexte politique et sociolinguistique propre à Israël. La traduction non littéraire comprend la traduction et l'interprétation officielles pour les médias et la traduction commerciale et universitaire. La traduction littéraire est étudiée des points de vue quantitatif et qualitatif et suivant les caractéristiques des traducteurs, la publication et la diffusion des ouvrages et leur réception par le public des lecteurs hébréophones israéliens.
Ce document est protégé par la loi sur le droit d'auteur. L'utilisation des services d'Érudit (y compris la reproduction) est assujettie à sa politique d'utilisation que vous pouvez consulter en ligne.

https://apropos.erudit.org/fr/usagers/politique-dutilisation/ 


\title{
TRANSLATION FROM ARABIC INTO HEBREW IN ISRAEL — AN OVERVIEW
}

\author{
HANNAH AMIT-KOCHAVI
}

Haifa University, Haifa, Israel

\begin{abstract}
Dedicated to the late Prof. Chaim Rabin (1915-1996), a pioneer of Israeli translator training, a great Hebrew scholar and a wonderful person.
\end{abstract}

\section{Résumé}

Cet article décrit l'état actuel de la traduction littéraire et non littéraire, de l'arabe vers l'hébreu, dans le contexte politique et sociolinguistique propre à Israël. La traduction non littéraire comprend la traduction et l'interprétation officielles pour les médias et la traduction commerciale et universitaire. La traduction littéraire est étudiée des points de vue quantitatif et qualitatif et suivant les caractéristiques des traducteurs, la publication et la diffusion des ouvrages et leur réception par le public des lecteurs hébréophones israéliens.

\section{Abstract}

This article describes the present state of literary and non-literary translation from Arabic into Hebrew in Israel within its particular political sociolinguistic context. Non-literary translations are subcategorized into official and media translation and interpretation, commercial translation and academic translation. Literary translation is described in terms of the number and nature of translated texts, translator characteristics, the publication and scope of the translations and their reception by Israeli Hebrew readers.

\section{INTRODUCTORY NOTES}

\section{The Language Situation}

Israel is located in the Middle East. Surrounded by Arab countries that share Arabic in its written form and are divided by abundant dialects, it is distinguished by its unique use of Hebrew as a main language. Arabic, the language of Israel's 18\% Arab minority, and English, a reminder of the British Mandate by which pre-state Israel was dominated (1917-1948), are two additional official languages.

Hebrew is Israel's dominant language, used in all aspects of government and education. It is the language of street signs and documents such as passports, stamps and currency. Members of the Israeli government and Knesset (Parliament) use it in their official speeches and the various media, including newspapers and journals, radio and television, are predominantly Hebrew. Hebrew also serves as the main language of education, both as a first language at Israeli Jewish schools and as a second language at Israeli Arab schools. It is the main language of instruction in higher education, with the exception of such language departments as English, French, Russian, etc. which lecture in their respective languages.

Arabic is the first language of Israeli Arabs, as well as many Oriental Jews, most of whom immigrated to Israel in the early 50s. Legally it serves as Israel's second official language and as such it may theoretically be used in all areas of life, both formal and informal. In actual practice, however, it is only partially present in Israeli life, except in major centres of Arab population. It is often dispensed with by many Israeli Arabs with a good 
command of Hebrew, especially in situations of contact with the Jewish majority (Weinreich 1953/1974). Thus, for example, most Arab Knesset members, although legally entitled to make their speeches in their mother language and have them professionally interpreted into Hebrew (Piamenta 1962), prefer to use Hebrew, so that the position of ArabicHebrew-Arabic Knesset interpreter, first introduced in the early 50s, is no longer filled. Arabic is only partially present in multilingual use - visible in street signs, identity cards, postage stamps and paper money, it is almost completely absent from small currency, official advertisements and most food products. In recent years, however, its presence has considerably increased in the two latter domains thanks to the Israeli Government's growing awareness of Israeli Arabs' right to equality and to the growing attraction of the Israeli Arab market for Israeli Jewish businessmen.

In the field of education, too, Hebrew and Arabic occupy unequal positions - Arabic, the main language of instruction at Israeli Arab schools, is only partially taught at Israeli Jewish schools. Despite a long tradition of its teaching at Jewish schools for the last 100 years or so (Landau 1962; Yonai 1992; Kinberg and Talmon 1994), it has only recently become an obligatory subject for 7th-9th grades at Jewish schools (Israeli Ministry of Education 1995), to be extended to 10th grade in the near future.

Arabic is taught at Israeli universities and colleges both as a major subject in Arabic departments and as an obligatory supplementary course in Middle East affairs and Hebrew Language departments. Until recently it has been taught through Hebrew, using a traditional method combining emphasis on grammar and verbal translation. Recently, however, the combined influence of political change and the introduction of modern second-language acquisition methods into Arabic teaching have emphasized the growing need for communicative Arabic. This has resulted in changes in school curricula and textbooks and in the obligatory use of Arabic as the language of instruction in second-language learning situations, first at schools and later also in university and college departments.

Arabic-Hebrew translator training has so far been scant. In fact, Israel has very few translator training frameworks, most of which are academic. The oldest one has been run by the Hebrew University of Jerusalem since 1971, first as a two-year certificate programme and then as a specialized trend and part of M.A. studies in Communication (Amit-Kochavi 1992). Arabic-Hebrew translation was a separate trend during the first stage and one of many different language pairs taught during the second one. Bar-Ilan University has been running a two-year translator and interpreter training certificate programme since 1972. Arabic-Hebrew translation, however, has only been taught there irregularly since the late 80s, and as theory rather than as actual practice. October 1994 saw the advent of a Hebrew-Arabic/Arabic-Hebrew translator training programme at Beit Berl College, including theoretical and practical training in both literary and non-literary translation, as well as a one-term course in interpreting. So far, however, the sorry history of Arabic-Hebrew translator training is reflected by the low number of professionals there are 3-4 professional interpreters, only one of whom has been academically trained, and a few dozen part-time practising translators, only four of whom are academically trained. The rest are Arabic speakers, both Arabs and Jews, occasionally recruited for the job as the occasion rises or permanently employed by Government and other official bodies and by the media, as will be elaborated below.

\section{Political Background}

The above description depicts some practical implications of the ongoing conflict between Israel and its Arab neighbours for the last 110 years or so, from the earliest Jewish Zionist settlement in a country sparsely populated by Arabs up to the ongoing peace process between Israel and a growing number of Arab countries, including Egypt, The 
Palestinian Authority, Jordan, Morocco, Syria and some of the Gulf Emirates. This conflict has gone through several stages - whereas pre-state Israel had to face Arab objection to Jewish land purchase and settlement, the Declaration of the State of Israel in 1948 made the Israeli-Arab conflict openly political, as reflected by a prolonged state of mutual hostility and several wars. This has made the word "Arab" almost synonymous with "enemy" to many Israeli Jewish ears and has affected Israeli official and individual attitude towards Israeli Arab citizens. As a result of all this, most Israeli Jews have little or no command of Arabic, and the psychological presence of the language is often ignored by Hebrew speakers. Recent changes in the political situation and Israeli-Arab relations since the late 70s, however, are beginning to be reflected by a mutual change of attitude and practice in the economic and cultural spheres that may eventually result in a growing demand for ArabicHebrew translation and interpretation.

\section{NON-LITERARY TRANSLATION}

\section{Official and Media Translation and Interpretation}

Since most official correspondence and documentation are dealt with in Hebrew, Arabic-Hebrew translation and interpretation are of limited scope. Military and other security bodies have their own translation facilities and training away from the public eye. Interpreting in legal proceedings (Morris 1993) is guaranteed by law to both Israeli citizens tried by Israeli courts and to those West Bank inhabitants subject to Israeli Military Government and tried by military courts. Interpreting is performed in both settings by non-professionals and its level is often unsatisfactory.

Like the Israeli Government, the Israeli media, too, are self-sufficient in filling their own Arabic-Hebrew translation and interpretation needs. Middle East and Arab affairs experts do their own translations of newspaper and journal articles, written and oral speeches and interviews. They often demonstrate high-level performance thanks to their subject-matter expertise, reinforced by direct activity in the field, in the West Bank and Gaza Strip as well as such Arab countries as Egypt and Jordan that are accessible to the Israeli media.

An outstanding exception to the self-service principle is TV subtitling. Israel has two major channels - Channel 1, run and sponsored by the Government, and the private Channel 2, on both of which many original and dubbed Arabic programmes are regularly subtitled into Hebrew. Whereas Channel 1 trains its own subtitlers in short but extensive courses, the commercial Channel 2 draws heavily on the scant Arabic-Hebrew translation services offered by a small number of translation companies concerned more with profit than with quality.

\section{Commercial Translation}

Commercial translation can only take place in a situation of economic contact and mutual interest. As outlined above, however, Israel still has very little open economic contact with its neighbours. In fact, the ongoing historical state of war made commercial contacts with the enemy forbidden by law on both sides. This was further aggravated by the overall Arab boycott of Israel. The lack of commercial activity naturally resulted in no translation activity either way (Arabic-Hebrew or Hebrew-Arabic). At present, however, some pioneering contacts are already underway between Israeli and Arab companies, so far more on the Hebrew-Arabic side than vice versa. 


\section{Academic Translation}

The above-described Israeli tradition of studying Arabic as a foreign language through Hebrew has been reflected by Israeli Hebrew research on Oriental Studies, in Arabic, Islamic Studies and Modern Middle East Affairs departments. Researchers often publish annotated editions of their translations of a variety of major texts. These include both classical texts such as The Holy Koran and collections of ancient Arabic poetry, and modern texts such as President Nasser's Philosophy of the Revolution, The PLO Charter and collections of political documents. All of these translations were personal efforts on the part of individual researchers and were published by different publishing houses. A single attempt to sponsor and regulate such translation activity was made in the 60s and early 70s by The Oriental Studies Institute affiliated to the Hebrew University of Jerusalem. Under the title The Translation Library it published a number of major classical Arabic texts, including historical and philosophical titles skillfully translated and annotated by experts.

Translations are also regularly included in academic books and articles in order to illustrate an academic point. Thus, for example, excerpts of literary pieces of all genres have been included in articles published in Hamizrach Hahadash (= New Orient), Israel's official publication in the field, to illustrate both literary and political articles, and in textbooks on Islamic history and culture and ancient and modern Arabic literature.

\section{LITERARY TRANSLATION}

\section{Texts}

Translated texts include both classical and Modern Arabic works. There are relatively few translations of classical works, including some major texts such as The Holy Koran (two translations), The Arabian Nights (both a full translation and a number of shorter adaptations) and three anthologies of ancient poetry, as well as a few historical, philosophical and mystical titles. Most of those texts were translated by academic professionals over a period from the earliest years of the 20th century up to the late 70s. apart from those anthologies of ancient Arabic poetry and a small number of poems published in a limited number of literary supplements of prestigious dailies, most of this material, prepared by scholars, never reached non-academic Israeli Hebrew readers.

Modern Arabic literature has been translated into Hebrew since 1931, including a variety of genres: poems, novels, short stories and plays that exemplify the literatures of most Arab countries: Egypt, Sudan, Lebanon, Syria, Iraq, Kuwait, Bahrein, Saudi Arabia, Yemen, Jordan, the West Bank, Morocco, Algeria, Tunisia, Libya, as well as Israeli Arabic literature (on Hebrew translations of the latter see Amit-Kochavi 1996).

Out of all Arabic literatures, the following are quantitatively predominant:

1) Egypt, the literary leader of the Arab world, has occupied a prominent position in the body of translations of prose works and drama in terms of both quality and quantity.

2) Palestinian literature on the one hand and Israeli Arabic literature on the other are quantitatively represented far beyond their real weight as Arabic literatures. This reflects Israeli Jewish interest in their political messages.

3) Syrian and Lebanese poetry have been translated due to their high artistic and innovative value.

The other Arabic literatures have been less widely translated, but their span has been widening, particularly through their growing representation in literary anthologies.

Like the countries, different genres, too, are unevenly represented within the translated text inventory. Out of almost 3000 items translated so far, only 31 are full-length 
novels, 16 are plays (including stage adaptations of novels and poems), and the rest, which constitute the lion's share of the works, are poems and short stories, some of which are included in about 40 translation anthologies. This predominance of short over long texts is due to the fact that most translators of Arabic literature into Hebrew translate on a parttime basis, and hence prefer to translate short texts.

So far no Arab writer's complete works are available to the Hebrew reader, with the following exceptions:

1) Eight novels and a number of short stories by Naguib Mahfuz, the Egyptian Nobel Prize winner, a long-time favourite with Israeli academic researchers, have been translated into Hebrew, and one novel, Whispers on the Nile, was also adapted into a play performed on the Hebrew stage.

2) Some of the short stories and all three novels of Israel Prize winner Emile Habibi have been translated into Hebrew. One novel, The Pessoptimist, is the only Arabic best-seller in Hebrew translation and its stage adaptation has been successfully performed in both Arabic and Hebrew for the last nine years.

As mentioned above, the first modern Arabic work translated into Hebrew was published in Tel Aviv as early as 1931, and translation activity has continued ever since. A historical survey shows that such political events as the Middle East wars (especially those of 1967, 1973 and 1982) were followed by an increase in the relative number of translations, and so was the Peace Treaty between Israel and Egypt (1979). Generally speaking, the number of translated works has gradually increased over the years, particularly since the 80s. The ongoing peace process in the Middle East will hopefully be followed by a greater increase in the number and spread of Arabic-Hebrew translations.

\section{Publication and Scope}

Translations from Arabic into Hebrew have been published in book form, literary magazines and newspaper weekend literary supplements, as well as various publications issued by such cultural bodies as Jewish-Arab mutual understanding societies, student unions and kibbutz local newsletters. Most prominent Israeli publishing houses have published Arabic novels and anthologies in Hebrew translation. The relatively small number of such publications is due more to the shortage of available material than to the lack of willingness to accept it for publication. Only a single prominent publishing house, Keter, has issued a regular series of translated Arabic works, and Mifras, a small radical publishing house has regularly included such works in all of its annual programmes.

Political standpoints propagating Israeli-Arab mutual understanding have been reflected by the regular publication of translated Arabic literature in two prominent literary magazines, Qeshet and 'Iton 77, that have also devoted entire issues to particular aspects of Arabic literature.

Since the 80s a growing number of Arabic works has been published in literary supplements of all the major Israeli newspapers.

Besides reading literary works, Israeli Hebrew-speakers also love the theatre. Over the years, a few Arabic plays have been performed on the Hebrew stage and a number of plays have been adapted from Arabic novels and poems. Most such theatrical events, however, have been staged by individual actors in fringe theatrical frameworks and have mostly failed to reach the general public.

\section{Reception of Translated Arabic Literature by Israeli Hebrew Readers}

Israel has a flourishing modern Hebrew literature, as well as a varied choice of the best of world literature in Hebrew translation. Arabic literature in Hebrew translation has 
been available for over 60 years now, but has had a relatively limited reading public due to the predominant Western orientation of Israeli Hebrew-speaking culture and to the presentation of the Arab as The Hostile Other in both Israeli politics and Hebrew literature (Ben Ezer 1992). Many readers of Arabic literature in Hebrew translation have been those already convinced of its relevance, but unable to read it in the source language. Individual works by great writers, however, have been favourably received, most notably Emile Habiby's first novel The Pessoptimist, brilliantly translated into Hebrew by Israeli Arab poet and writer Anton Shammas (Somekh 1993).

\section{Translators}

Translators of Arabic literature into Hebrew may be subdivided according to their country of origin, nationality and command of Arabic (either as mother tongue or as foreign language). Translators of classical Arabic have all been scholars of either Oriental or East European origin. Translators of Modern Arabic literature all share an ardent ideological belief in their mission as intercultural bridge-builders, but most of them actually translated relatively small numbers of works over long periods, as only a single translator, Rachel Halabe, has worked full-time.

In terms of country of origin and command of languages, the earliest translators were East European Jews with a good command of both Arabic and Hebrew. A second type of translator emerged after the mass immigration from the Arab countries to Israel during the early 50s. Some of these had already made themselves a name in the literary circles of their home countries. Once in Israel, they first joined local Arabic journals and later became Hebrew writers, university lecturers on Modern Arabic literature, or both. They have translated texts pertaining to their academic interests, as well as texts of high poetic and literary quality.

A third type emerged side by side with the previous two, including Israeli-born native Hebrew-speaking Jews, born in the 20s and 30s with an academic education in Arabic language and literature. These, too, have combined academic research with part time literary translation.

A fourth type includes a younger generation, born in the 40s and 50s, otherwise similar to the previous one. Some members of this group not only studied Arabic, but were also academically trained as literary translators.

A fifth type comprises Israeli Arabs and Druze, born and educated in Israel since the 50s, whose excellent command of both Arabic and Hebrew has qualified them to translate Arabic literature into Hebrew. Some of these are also poets and writers writing in both Arabic and Hebrew who have played an active part in Israeli Hebrew and Arabic cultural life as writers, journalists, editors and literary critics.

It should be emphasized that subdivision into translator types and generations is slightly misleading, as members of different groups have been simultaneously active over long periods.

\section{CONCLUDING REMARKS}

Translation from Arabic into Hebrew has been present in Israeli life unnoticed by most Israeli Hebrew speakers. The ongoing change in Israeli-Arab relations from mutual threat to mutual cooperation will most probably be reflected by greater public awareness of the need for this kind of translation. The extent and ways in which this is to happen remain to be seen. 


\section{REFERENCES}

AMIT-KOCHAVI, Hannah (1992) : "Moving Translator Training from the Humanities to the Social Sciences: an Israeli Case Study", Cay Dollerup and Anne Loddegaard (Eds), Teaching Translation and Interpreting: Training, Talent and Experience, Amsterdam/Philadelphia, John Benjamins Publishing Company, pp. 9397.

AMIT-KOCHAVI, Hannah (1996) : "Israeli Arabic Literature in Hebrew Translation — Initiation, Dissemination and Reception", The Translator, 2 (1), Manchester, St. Jerome Publishing, pp. 27-44.

BEN EZER, Ehud (1992) : In the Homeland of Conflicting Longing, the Depiction of the Arab Figure in Hebrew Literature, Tel Aviv. [Hebrew]

The Israeli Minsitry of Education (1995) : "Language Education Policy in Israel", excerpts from General Director's Communique 25/10, Majallat al-Mu'allim, Journal of the Teachers of Arabic in Hebrew-Speaking Schools, 19, Givat Haviva, The Institute for Arabic Studies, pp. 8-10. [Hebrew]

KINBERG, Naftali and Rafael TALMON (1994) : "Learning of Arabic by Jews and the Use of Hebrew among Arabs in Israel", IJOAL, XX (1-2), pp. 37-54

LANDAU, Jacob M. (Ed.) (1962) : The Teaching of Arabic as a Foreign Language, Jerusalem, The Hebrew University School of Education and the Israeli Ministry of Education and Culture. [Hebrew]

MORRIS, Ruth (1993) : Images of the Interpreter: a Study of Language-Switching in the Legal Process, Ph.D. thesis, Department of Law, Lancaster University.

PIAMENTA, Moshe (1962) : Hebrew-Arabic Dictionary for Parliamentary Procedure and Meetings, Jerusalem, Bureau of the Arab Affair Special Consultant, Prime Minister's office.

SOMEKH, Sasson (1993) : "Anton Shammas — Translation as a Challenge", Sasson Somekh (Ed.), Translation as a Challenge, Papers on Translation of Arabic Literature into Hebrew, Tel Aviv, Tel Aviv University \& the Institute for Arabic Studies, Givat Haviva, pp. 41-51.

WEINREICH, Uriel (1953/1974) : Languages in Contact, Findings and Problems, The Hague \& Paris, Mouton.

YONAI, Yoseph (Ed.) (1992) : Arabic at Hebrew Schools, Collected Documents, Jerusalem, Ministry of Education and Culture, Section of History of Education and Culture. [Hebrew] 